\title{
New copolymers with triazole pendant groups: Synthesis, characterization and their application to remove heavy metals
}

\author{
Melisa Lamanna ${ }^{1,2}$, Lorena Leiton ${ }^{3}$, Isabel N. Vega ${ }^{4}$, Bernabé L. Rivas ${ }^{3}$, and Norma D'Accorso ${ }^{1,2 *}$ \\ ${ }^{1}$ CONICET- Universidad de Buenos Aires. Centro de Investigaciones en Hidratos de Carbono, (CIHIDECAR), Buenos Aires, Argentina \\ ${ }^{2}$ Universidad de Buenos Aires, Facultad de Ciencias Exactas y Naturales, Departamento de Química Orgánica, Buenos Aires, Argentina \\ ${ }^{3}$ Polymer Department, Faculty of Chemistry, University of Concepción, Casilla 160-C, Concepción, Chile \\ ${ }^{4}$ YPF Tecnología, Baradero s/n CP 1925 Ensenada, Buenos Aires, Argentina
}

\begin{abstract}
Copolymers obtained from polyvinyl alcohol (PVA) containing substituted triazole pendant groups were synthesized via "click" reactions. The chemical structures of the new copolymers with hydroxyl methyl (PVATPHM) or protected galactosyl groups (PVATPGal) as substituents were characterized by spectro scopical analysis (FTIR, ${ }^{13} \mathrm{C}$ NMR, and ${ }^{1} \mathrm{H}$ NMR spectroscopies) as well as the thermal properties were analyzed by TGA and DSC techniques. Interactions studies with heavy metal ions, such as $\mathrm{Cd}^{2+}, \mathrm{Zn}^{2+}, \mathrm{Hg}^{2+}$, and $\mathrm{Cu}^{2+}$, in aqueous solutions were carried out. Ion sorption was evaluated taking into account pH, time, and concentration. Results of competitive selectivity assays were also analyzed. PVATPHM was capable to remove all the analyzed metal ions in different experimental conditions. Furthermore, the PVATPGal showed excellent capacity for lead removal with maximum adsorption capacity at pH 1.0 and the heavy metal can be desorbed using ethylenediaminetetraacetic acid.
\end{abstract}

\section{Introduction}

PVA is a versatile polymer that can suffers chemical modification or physical interactions that lead to new materials with improved properties; for example, Vega et al. have reported stiff gels by PVA and Congo red interaction that can be used as hydraulic fracturing liquids [1]. Moreover, attempt was made to prepare an interpenetrated network hydrogel microsphere by using PVA and locust bean gum for oral controlled drug delivery [2]. Such modification may provide PVA with pendant functional groups or graft polymer chains, and thus expand their applications in different fields. The typical PVA chemical modification includes esterification, etherification or acetalyzation of the hydroxyl groups [3]. On the other hand, the azide/alkyne 'click' reaction [4] is a recent re-discovery of a reaction fulfilling many requirements for the affixation of ligands onto polymers by postmodification processes, which include: often quantitative yields, a high tolerance of functional groups, an insensitivity of the reaction to solvents, irrespective of their protic/aprotic or polar/non-polar character, and reactions at various types of interfaces interfaces $[5,6]$. This methodology is appropriate to obtain five members heterocyclic rings, particularly 1,2,3-triazole. Yacgi et al. [7] used a convergent strategy to obtain chromophoric pendant groups incorporated to the modified PVA.

It is well known the ability to coordinate metal ions of the $N$-heterocyclic groups [8,9]. For example, the strong coordination of tetrazole, triazole, and its derivatives to metal ions makes them attractive ligands, and because of that they were used as bridging ligands in coordination chemistry $[10,11]$.

The presence of heavy metal ions in the environment is one of the major concerns due to their toxicity to many life forms. They are introduced into the environment during industrial processes, refining of ores, mining, disposal of industrial and domestic waters, etc. Pollution in water concern to worldwide due the toxic effect on humans hence it needs the immediate attention of researchers and environmentalists $[12,13]$. Polymer resins and hydrogels bearing electron donor groups have the ability to bind metal cations [15-20]. Mercury is generally considered to be one of the most toxic metals found in the environment [21] and that is why the discharge limit of waste water streams has been fixed by law in very small values.

In search of new materials capable of capturing heavy metals, in previous works we reported the chemical modification of an industrial polymer capable to remove copper from an aqueous solution [22,23]. Therefore, the aim of this work is to synthesize new copolymers from PVA, containing triazole pendant groups, and evaluate their capacity as heavy metal ions removal agents.

\section{Experimental}

\section{Materials}

PVA (98+\%, 89000-98000 g/mol, Aldrich Co), dimethyl formamide (DMF), ethanol $(\geq 99.5 \%)$, diethylether (98\%, Sigma-Aldrich), methanol (99\%), dimethyl sulfoxide (DMSO, $\geq 99 \%)$, anhydrous

Correspondence to: Norma D'Accorso, CONICET- Universidad de Buenos Aires, Centro de Investigaciones en Hidratos de Carbono (CIHIDECAR), Buenos Aires, Argentina, E-mail: norma@qo.fcen.uba.ar

Key words: Poly(vinyl alcohol), "click" reaction, triazole, heavy metal removal

Received: March 03, 2017; Accepted: April 07, 2017; Published: April 11, 2017 
pyridine, sodium azide, copper(II) sulfate $\left(\mathrm{CuSO}_{4} \cdot 5 \mathrm{H}_{2} \mathrm{O}\right)$, L-ascorbic acid, toluene-4-sulfonic acid monohydrate (PTSA), propargyl alcohol and all the solvents employed were obtained from commercial suppliers (Aldrich $\mathrm{Co}$ ) and used as received. Metal nitrate salts $\left(\mathrm{Cd}\left(\mathrm{NO}_{3}\right)_{2} \cdot 4 \mathrm{H}_{2} \mathrm{O}, \mathrm{Hg}\left(\mathrm{NO}_{3}\right)_{2} \cdot \mathrm{H}_{2} \mathrm{O}, \mathrm{Cu}\left(\mathrm{NO}_{3}\right)_{2} .5 \mathrm{H}_{2} \mathrm{O}, \mathrm{Zn}\left(\mathrm{NO}_{3}\right)_{2} \cdot 6 \mathrm{H}_{2} \mathrm{O}\right)$ were purchased from Merck Company. For resin elution experiments ethylene diaminetetra acetic acid (EDTA, Sigma-Aldrich) and sodium bicarbonate (AP, Fluka) were used.

\section{Characterization and measurements}

Chemical characterization: Fourier Infrared transmission (FTIR) spectra of the samples were performed on a Nicolet FT-IR Instrument $510 \mathrm{P}$. For this purpose, $\mathrm{KBr}$ and solid polymer pellets were prepared.

Nuclear magnetic resonance (NMR) spectra were obtained on a Brucker AC $200 \mathrm{MHz}$ or Brucker $500 \mathrm{MHz}$ spectrometer, using DMSO- $\mathrm{d}_{6}$ as solvent.

Differential scanning calorimetry (DSC) measurements were performed on a TA Q series TM Q20-1041 TA Instruments - Waters LLC. Sample weights from $1.5-2.5 \mathrm{mg}$ in aluminum pans were used. The equipment was calibrated with indium standard. The samples were heated from 20 to $150^{\circ} \mathrm{C}$ at a heating rate of $5^{\circ} \mathrm{C} / \mathrm{min}$, under $\mathrm{N}_{2}$ atmosphere. Thermogravimetry (TGA) was carried out on a TGA-51 Shimadzu thermogravimetric analyzer. The nitrogen flux rate was 40 $\mathrm{mL} / \mathrm{min}$ and the temperature range was from 25 to $500^{\circ} \mathrm{C}$ at a heating rate of $5^{\circ} \mathrm{C} / \mathrm{min}$ with sample weights of $4.0-6.0 \mathrm{mg}$.

Metal ion sorption experiments: Sorption experiments were carried out by batch equilibrium procedure to determine the metal ion binding ability of synthesized adsorbents. All experiments were performed in a test tube using a total of $0.05 \mathrm{~g}$ of dry resin and $5 \mathrm{~mL}$ of metal ion solution at determined $\mathrm{pH}$. The tubes were placed in a shaker equipped with a thermoregulated bath, during $1 \mathrm{~h}$ at $20^{\circ} \mathrm{C}$ and $140 \mathrm{rpm}$. The sorption experiments were performed and the effect of $\mathrm{pH}$, contact time, maximum retention capacity, and temperature were evaluated. The resin/metal ion ratio used for all experiments was 20:1 (in mol), nitrate salts were employed in all cases (Cd(II), $\mathrm{Hg}(\mathrm{II}), \mathrm{Cu}(\mathrm{II})$, and $\mathrm{Zn}(\mathrm{II}))$, $\mathrm{pH}$ of each solution was adjusted with $\mathrm{HNO}_{3}$ and $\mathrm{NaOH}$, as was required, by the use of $\mathrm{pH}$ meter.

In addition, the retention ability for divalent cations was studied under competitive conditions using a ternary mixture of $\mathrm{Hg}-\mathrm{Zn}-\mathrm{Cd}$ at $\mathrm{pH} 1$ to evaluate the selectivity properties of synthesized resins. Once contact experiments were accomplished, resins samples were filtered and washed with water at the same $\mathrm{pH}$ and concentrations of metal ions in the filtrate were determined by atomic absorption spectroscopy.

To determine the maximum sorption capacity the experiments were carried out contacting $25 \mathrm{~mL}$ of an aqueous solution of each metal ion $(1.0 \mathrm{~g} / \mathrm{L})$ with $0.50 \mathrm{~g}$ of dry resin at $20^{\circ} \mathrm{C}$ and $140 \mathrm{rpm}$. The process was repeated twice and samples were handled as mentioned above.

Elution experiments were carried out using $\mathrm{NaHCO}_{3}$ and EDTA as potential stripping reagents at concentration of $0.5 \mathrm{M}$. Experiments were carried out by batch procedure contacting $0.05 \mathrm{~g}$ of resin loaded with ions, and $5 \mathrm{~mL}$ of eluent for $1 \mathrm{~h}$ at $20^{\circ} \mathrm{C}$ and $140 \mathrm{rpm}$.

Metal ion concentrations of stock and filtrated solutions were determined by atomic absorption spectrometer (AAS) model Unicam Solaar $5 \mathrm{M}$ series.

\section{Methodology}

Synthesis of copolymer from PVA with 4-hydroximethyl-1,2,3triazolyl pendants groups (PVATPHM): Partial tosylation of PVA with $p$-toluene sulfonyl chloride (p-TsCl; $1: 1$; in terms of hydroxyl moieties) in the presence of anhydrous pyridine at room temperature yielded PVA-Ts [7].

After six hours, the reaction work up was done pouring them on water. Then, all the samples were filtered, washed exhaustively with hydrochloric acid and then with water, then washed with sodium bicarbonate. Finally, they were sonicated in distilled water for $1 \mathrm{~h}$. The solids were dried with vacuum pump to constant weight, with $12 \%$ of percent conversion of hydroxyl in tosyl groups. Degree of tosylation reaction was obtained from ${ }^{1} \mathrm{H}$ RMN spectrum. Areas from aromatic and methyne protons (signals between 7-8 ppm and $3.9 \mathrm{ppm}$, respectively) were analyzed to determinate these values [7].

The treatment of PVA-Ts (260 mg, $4.3 \mathrm{mmol}$ ) with $\mathrm{NaN}_{3}(279 \mathrm{mg}$, $4.3 \mathrm{mmol}$ ) in DMF(anhydrous) during $48 \mathrm{~h}$ at $65^{\circ} \mathrm{C}$ in $\mathrm{Ar}$ atmosphere, lead to a copolymer with some azide as pendant groups (PVA-N3). Then, the reaction was precipitated into excess ethyl ether, filtered, sonicated in ethyl ether $(1 \mathrm{~h})$ and filtered again. Finally, the obtained solid was dried under vacuum pump (3.2\% conversion). In the ${ }^{1} \mathrm{H}$ NMR spectrum the signal of $-\mathrm{CH}$ substituted with azido was observed at $4.02 \mathrm{ppm}$ meanwhile in ${ }^{13} \mathrm{C}$ NMR spectrum a signal at $56 \mathrm{ppm}$ was attributed to carbon of these groups.

In order to perform 'click' reaction, PVA-N3 (250 mg) was mixed with propargyl alcohol $(0.05 \mathrm{~mL})$ in $5 \mathrm{~mL}$ of DMF. The reaction was carried out at room temperature for $70 \mathrm{~h}$. A freshly prepared aqueous solution of sodium ascorbate $(68 \mathrm{mg}, 0.34 \mathrm{mmol})$ was employed as reaction catalyst. Then, a solution of copper sulfate aqueous (I) pentahydrate $(17 \mathrm{mg}, 0.068 \mathrm{mmol})$ was added. When the reaction finished, it was precipitated into ethyl ether (excess), filtered, and dried under vacuum. The new copolymers with triazolic rings (PVATPHM) were obtained and near-quantitative functionalization was achieved.

Synthesis of copolymer with galactosyl derivative substituent of 1,2,3-triazolyl as pendants groups (PVATPGal): A similar procedure applied to obtain PVATPHM was used to synthesize PVATPGal. In this case, PVAN3 reacted with 1,2:3,4-di-O-isopropylidene-6-O-(2propinyl)- $\alpha$-D-galactopyranose [24] as dipolarophile. PVATPGal was quantitatively obtained.

In Figure 1 is shown the synthetic pathway employed to obtain PVATPHM and PVATPGal.

\section{Results and discussion}

\section{FTIR characterization}

In Figure 2 are shown the FTIR spectra for PVA-N3, PVATPHM, and PVATPGal. In the case of PVA-N3 it can be seen the characteristic signal of the azide group at $2094 \mathrm{~cm}^{-1}$ [7], which is very intense and shows the effective replacement of the tosyl groups. Regarding samples PVATPHM and PVATPGal the fingerprint area differs not only among themselves but also with respect to the precursor, in this case PVA-N3. In PVATPHM and PVATPGal spectra, the effectiveness of click reactions could be confirmed by the absence of the characteristic band of the azide group. Indeed, it could be observed absorption bands between $\left.1680-1690 \mathrm{~cm}^{-1}(\mathrm{C}=\mathrm{N})\right)$. In particular, the PVATPGal spectrum shows a markedly increase of the relative intensity of the signal corresponding to $\mathrm{CH}$ stretching $\left(2800 \mathrm{~cm}^{-1}\right)$ which is consistent with the incorporation of the protected galactosyl moiety.

\section{NMR characterization}

The ${ }^{1} \mathrm{H}$ NMR spectrum of PVA-N3 is in agreement with the results reported by Yacgi et al. [7], where a signal at $4.02 \mathrm{ppm}$ is due to $-\mathrm{CHN}_{3}$. 


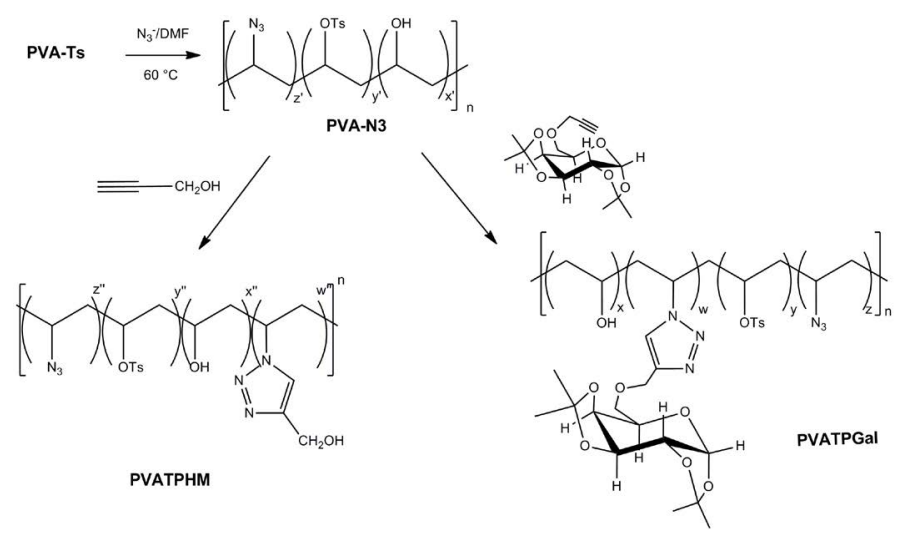

Figure 1. Synthetic pathway to obtain PVA-N3 and subsequent click reactions to obtain PVATPHM and PVATPGal.

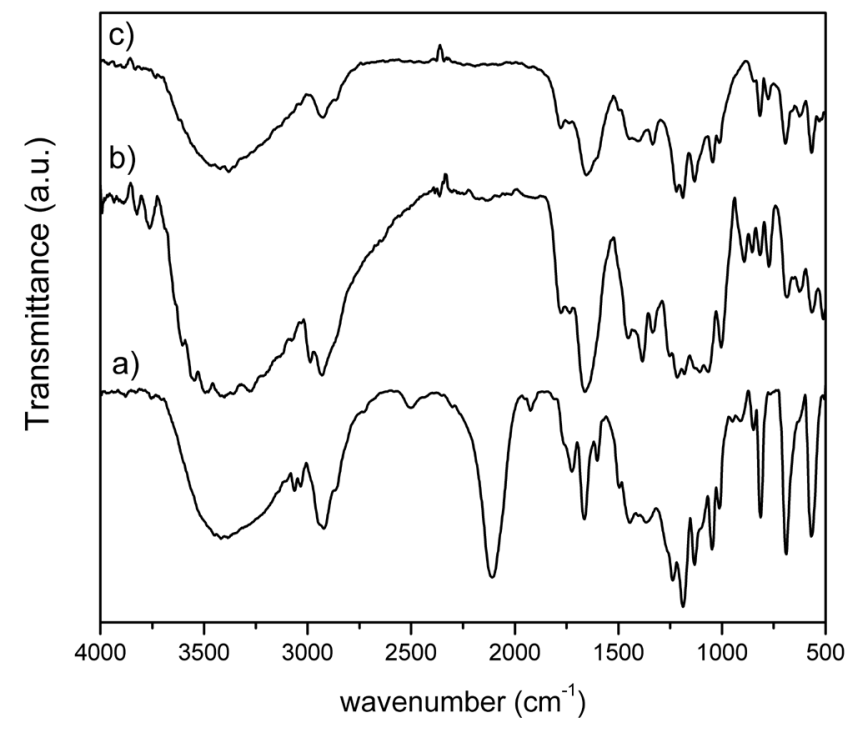

Figure 2. FTIR spectra for a) PVA-N3, PVATPGal and c) PVATPHM.

Figure 3 shows the ${ }^{1} \mathrm{H}$ NMR (DMSO d ) $_{6}$ spectra for samples PVATPHM and PVATPGal, in which it could be observed the modifications of methyne protons neighboring substituent groups (azido, triazole derivatives). In the case of PVATPHM and PVATPGal methyne and methylene signals are observed at 3.2-3.8 ppm and at $1.3-1.6 \mathrm{ppm}$, respectively. In particular, in the PVATPGAl spectrum a signal at 5.43 $\mathrm{ppm}$ is an evidence to confirm the presence of the carbohydrate residue. This signal corresponds to the anomeric protons of the carbohydrate and appears as a broad signal due to wide variations in its chemical environment, indicating that the click reaction had occurred.

The ${ }^{13} \mathrm{C}$ NMR spectra analyzed confirmed the modifications and are shown in Figure 4. In the spectrum (DMSO d ) of PVA-N3 it can be seen a signal at $56 \mathrm{ppm}$ which corresponds to the carbon attached to the azide group. This signal is absent in PVATPHM and PVATPGal spectra. In PVATPGal spectrum signals at $90 \mathrm{ppm}$ appeared due to the anomeric carbons of different arrangements involving galactose residues as triazole substituent. Also, methyl carbons of isopropylidene groups are observed between 23-27 ppm, meanwhile at $110 \mathrm{ppm}$ appears the signal of quaternary carbons of this protected group. These signals can be considered as an evidence of effectiveness of click reaction. For all copolymers signals were observed between 120-130 ppm due to the aromatic carbons of the tosyl group.

\section{Thermal characterization}

Thermogravimetric analyses were done for PVA-N3, PVATPHM, and PVATPGal. The thermal stability for the new copolymers was higher than their precursor (PVA-Ts). For all the samples, the highest mass loss occurs at temperatures above $200^{\circ} \mathrm{C}$ (see Supplementary Data - TGA Table). Besides, DSC characterization was performed between 25 at 200, from these results (see Supplementary Data - TGA Figure) it can be seen that PVATPHM and PVATPGal does not show melting endothermic peak in the studied temperature range. These copolymers melt with decomposition at higher temperatures. However, glass transition temperatures ( $\mathrm{Tg}$ ) could be determinate, both samples have higher Tg values than their polymer precursor (PVAN3), this fact was probably due to the presence of the heterocyclic rings that enhance the chains interactions. Also, both PVATPHM and PVATPGal were more thermally stable (higher decomposition temperature) in comparison with their precursor (PVA-N3).

\section{Aplications as heavy metals removal}

PVA-Ts: Since this is an intermediate in the synthesis copolymer and has the sulfur substituent groups, retention was tested only with $\mathrm{Hg}(\mathrm{II})$ at $\mathrm{pH} 1$, since it is presumed that interaction with metal ions could occur only through the sulfur and it is well known that this has a high affinity for $\mathrm{Hg}(\mathrm{II})$. Test was made to determine the maximum retention capacity (MRC). Table 1 summarizes of the results.

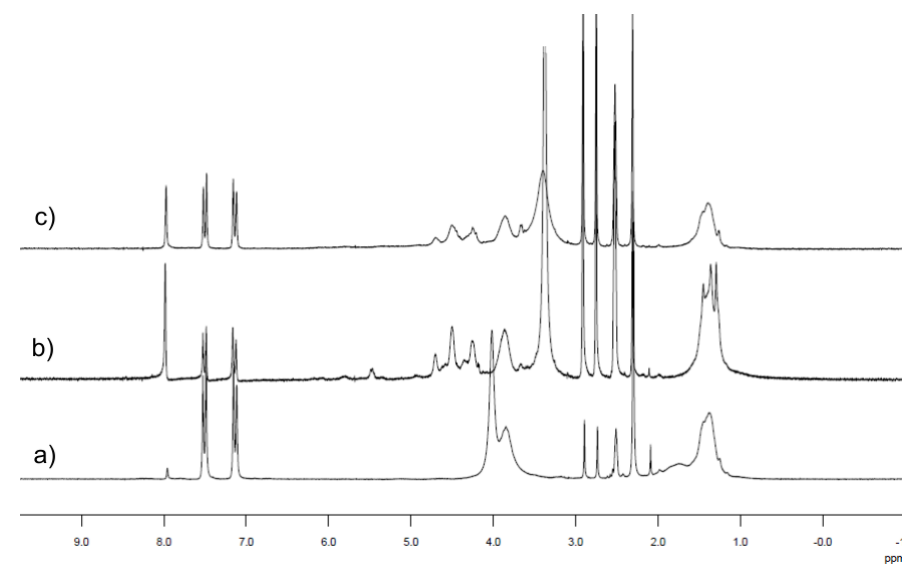

Figure 3. 'H NMR spectra for a) PVA-N3, b) PVATPGal, and c) PVATPHM.

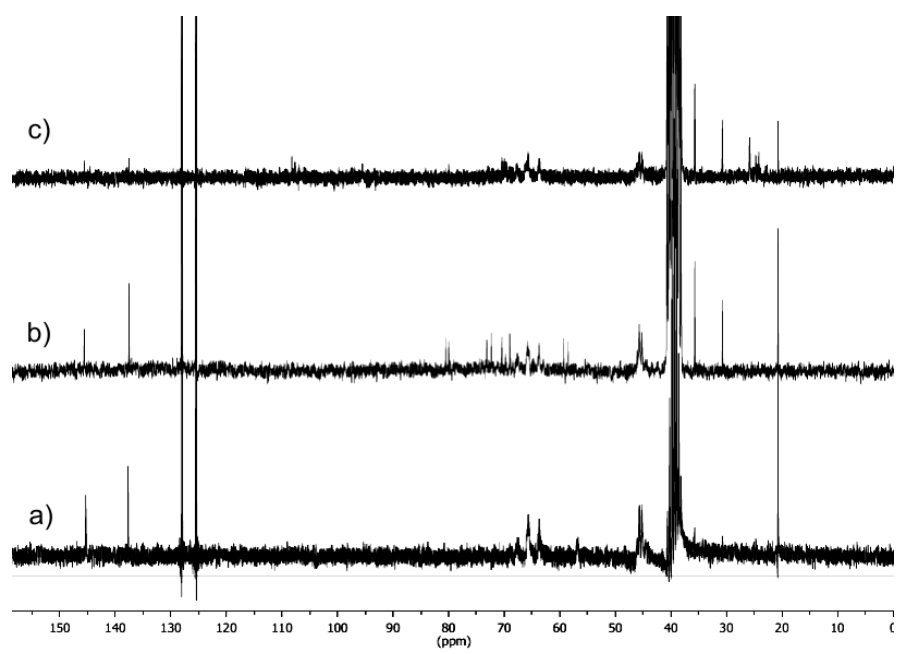

Figure 4. ${ }^{13} \mathrm{C}$ NMR spectra for a) PVA-N3, b) PVATPHM, and c) PVATPGal. 


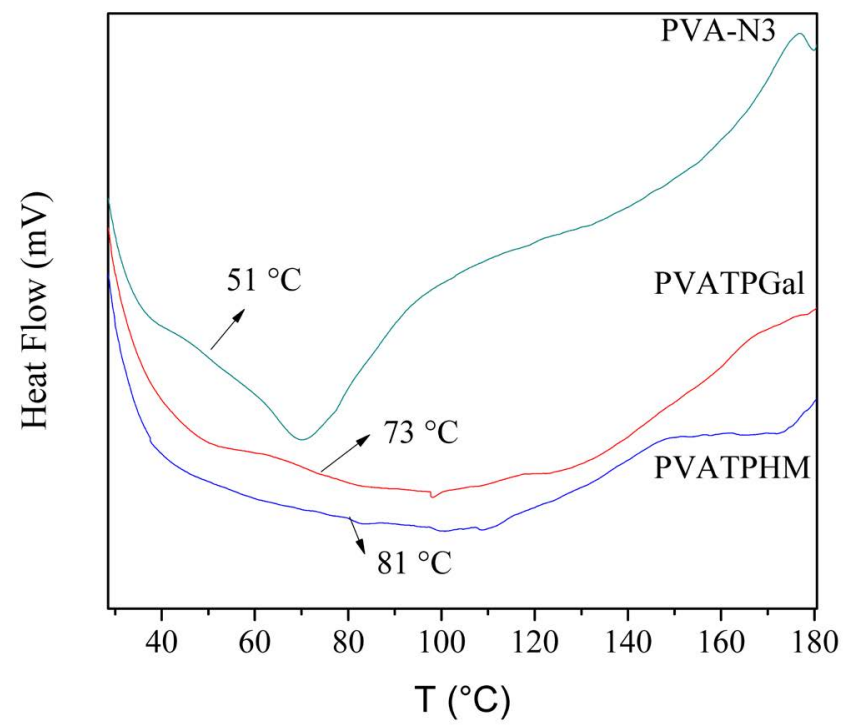

Figure 5. DSC results for PVA-Ts, PVATPGal, and PVATPHM.

Table 1. MRC results obtained for PVA-Ts. (MRC maximum retention capacity, \% R: retention percent, $\mathrm{mg} \mathrm{R} / \mathrm{g}$ Pol: retained $\mathrm{mg}$ per gram of polymer)

\begin{tabular}{|c|c|c|c|c|}
\hline & $\begin{array}{l}\mathrm{R} \\
(\%)\end{array}$ & $\begin{array}{c}\mathrm{R} \\
(\mathrm{mg} / \mathrm{g} \text { pol) }\end{array}$ & $\begin{array}{l}\text { TOTAL retained } \\
(\mathrm{mg})\end{array}$ & $\begin{array}{c}\text { MRC } \\
(\mathrm{mg} / \mathrm{g} \mathrm{pol})\end{array}$ \\
\hline $\mathrm{RC} 1$ & 69.9 & 28.20 & \multirow{3}{*}{8.31} & \multirow{3}{*}{82.73} \\
\hline $\mathrm{RC} 2$ & 14.9 & 6.03 & & \\
\hline RC3 & 10.1 & 4.09 & & \\
\hline
\end{tabular}

From the results obtained in the study of retention capacity, it is observed that the PVA-Ts was saturated in the first contact assay, and then the retention rate dramatically decreased.

As was mentioned above, PVATPHM has a ring-triazole directly bonded to the polymer chain, which has a hydroxyl group as a substituent. Because it has suitable characteristics to coordinate with metal ions, assays were performed to study the effect of $\mathrm{pH}$ for retention of $\mathrm{Cu}(\mathrm{II}), \mathrm{Cd}(\mathrm{II}), \mathrm{Zn}(\mathrm{II})$, and $\mathrm{Hg}(\mathrm{II})$. All metal ions were tested at $\mathrm{pH}$ 1,3 , and 5 , except $\mathrm{Hg}(\mathrm{II})$ which was tested only at $\mathrm{pH} 1$ due to, at high concentrations like we used, at $\mathrm{pH} 2$ the precipitation of the salt was observed. In Table 2 are shown the results for each of the metal ions at different $\mathrm{pHs}$.

Due to the $\mathrm{R}$ (\%) obtained for copper ion (II) was very low at $\mathrm{pH}$ 1 and higher than $70 \%$ at $\mathrm{pH} 3$, these differences could be useful for releasing retention cycles according to the $\mathrm{pH}$ value allowing recovery the polymer. It was observed that the highest percentage of retention is obtained with the mercury ion (II) at $\mathrm{pH} 1$, so it was decided to analyze the maximum retention capacity for such metal only. In Table 3 are shown the results for this last analysis.

PVATPGal: PVATPGal has a triazole ring directly attached to the hydrocarbon chain of the polymer, which in turn is substituted with a galactose residue. Then, it was decided to study the effect of $\mathrm{pH}$ for retention of the metallic ions $\mathrm{Cu}$ (II), Cd (II), $\mathrm{Zn}$ (II) and $\mathrm{Hg}$ (II). The obtained results are shown in Table 4.

From this analysis, it was observed that the mercury ion (II) is highly removed by the polymer PVATPGal. For this reason, it was decided to develop the following studies on the interaction of this polymer with the metal ion $\mathrm{Hg}(\mathrm{II})$ that led to describe in detail the coordination:

\section{Determination of the MRC of $\mathrm{Hg}$ (II) for the PVATPGal}

It was observed that the highest retention percent was obtained with the mercury ion (II) at $\mathrm{pH} 1$, so it was decided to analyze the maximum retention capacity for this metal (see Table 5).

From this analysis, it could be seen that PVATPGal has its maximum retention on the first contact, then the polymer saturates and the retention rate decreases about $50 \%$ compared to the first one.

Influence of $\mathrm{Hg}(\mathrm{II})$ concentration in retention with PVATPGal

Different solutions were prepared from $\mathrm{Hg}$ (II), which had the following molar ratios with respect to the repetitive unit of the PVATPGal triazole groups (PVA-Gal: Hg (II)): (20:0.1), (20:0.5), (20:1), (20:1.5). All the results obtained are summarized in Table 6.

Tabla 2. $\mathrm{pH}$ influence on metal ion retention for PVATPHM

\begin{tabular}{|c|c|c|c|}
\hline PVATPHM & $\mathrm{pH}$ & $\begin{array}{c}\mathrm{R} \\
(\%)\end{array}$ & $\begin{array}{c}\mathrm{R} \\
(\mathrm{mg} / \mathrm{g} \text { pol })\end{array}$ \\
\hline $\mathrm{Cu}(\mathrm{II})$ & 1 & $\mathrm{Nd}^{*}$ & $\mathrm{Nd}$ \\
\hline $\mathrm{Cu}(\mathrm{II})$ & 3 & 73.8 & 124.00 \\
\hline $\mathrm{Cu}(\mathrm{II})$ & 5 & 70.4 & 155.41 \\
\hline $\mathrm{Cd}(\mathrm{II})$ & 1 & $\mathrm{Nd}$ & $\mathrm{Nd}$ \\
\hline $\mathrm{Cd}(\mathrm{II})$ & 3 & 63.3 & 170.46 \\
\hline $\mathrm{Cd}(\mathrm{II})$ & 5 & 51.2 & 131.94 \\
\hline $\mathrm{Zn}(\mathrm{II})$ & 1 & $\mathrm{Nd}$ & $\mathrm{Nd}$ \\
\hline $\mathrm{Zn}(\mathrm{II})$ & 3 & 33.6 & 52.47 \\
\hline $\mathrm{Zn}(\mathrm{II})$ & 5 & 27.6 & 44.17 \\
\hline $\operatorname{Hg}(\mathrm{II})$ & 1 & 91.6 & 70.09 \\
\hline
\end{tabular}

"Nd: not determined values due to metal ion concentration obtained in the contact was higher than that initial one, the zero difference is attributable to experimental error.

Table 3. MRC results obtained for PVATPHM.

\begin{tabular}{|c|c|c|c|c|c|}
\hline \multirow{2}{*}{} & & $\begin{array}{c}\mathrm{R} \\
(\%)\end{array}$ & $\begin{array}{c}\mathrm{R} \\
(\mathrm{mg} / \mathrm{g} \text { pol })\end{array}$ & $\begin{array}{c}\text { TOTAL } \\
\text { retained } \\
(\mathrm{mg})\end{array}$ & $\begin{array}{c}\text { MRC } \\
(\mathrm{mg} / \mathrm{g} \text { pol })\end{array}$ \\
\hline \multirow{3}{*}{$\mathrm{Hg}(\mathrm{II})$} & $\mathrm{RC} 1$ & 64.26 & 54.17 & & \multirow{2}{*}{113.36} \\
\cline { 2 - 4 } & $\mathrm{RC} 2$ & 49.98 & 42.12 & 11.34 & \multirow{2}{*}{} \\
\cline { 2 - 4 } & $\mathrm{RC} 3$ & 51.30 & 43.24 & & \\
\hline
\end{tabular}

Table 4. $\mathrm{pH}$ influence on metal ion retention for PVATPGal

\begin{tabular}{|c|c|c|c|}
\hline Metal ion & $\mathrm{pH}$ & $\begin{array}{c}\mathrm{R} \\
(\%)\end{array}$ & $\begin{array}{c}\mathrm{R} \\
(\mathrm{mg} / \mathrm{g} \text { pol })\end{array}$ \\
\hline $\mathrm{Cu}(\mathrm{II})$ & 1 & 5.9 & 5.10 \\
\hline $\mathrm{Cu}(\mathrm{II})$ & 3 & $\mathrm{Nd}$ & $\mathrm{Nd}^{*}$ \\
\hline $\mathrm{Cu}(\mathrm{II})$ & 5 & 13.4 & 11.32 \\
\hline $\mathrm{Cd}(\mathrm{II})$ & 1 & 13.3 & 11.52 \\
\hline $\mathrm{Cd}(\mathrm{II})$ & 3 & 17.5 & 13.41 \\
\hline $\mathrm{Cd}(\mathrm{II})$ & 5 & 20.7 & 16.47 \\
\hline $\mathrm{Zn}(\mathrm{II})$ & 1 & 12.2 & 14.49 \\
\hline $\mathrm{Zn}(\mathrm{II})$ & 3 & 9.2 & 10.03 \\
\hline $\mathrm{Zn}(\mathrm{II})$ & 5 & 11.8 & 9.42 \\
\hline $\mathrm{Hg}(\mathrm{II})$ & 1 & 95.1 & 288.25 \\
\hline
\end{tabular}

"Nd: not determined values due to metal ion concentration obtained in the contact was greater than initial one, the zero difference is attributable to experimental error.

Table 5. MRC results obtained for PVATPGal.

\begin{tabular}{|c|c|c|c|c|c|}
\hline \multirow{2}{*}{} & & $\begin{array}{c}\mathrm{R} \\
(\%)\end{array}$ & $\begin{array}{c}\mathrm{R} \\
(\mathrm{mg} \mathrm{g} \text { Pol })\end{array}$ & $\begin{array}{c}\text { TOTAL } \\
\text { retained } \\
(\mathrm{mg})\end{array}$ & $\begin{array}{c}\text { MRC } \\
(\mathrm{mg} / \mathrm{g} \text { pol })\end{array}$ \\
\hline \multirow{3}{*}{$\mathrm{Hg}(\mathrm{II})$} & $\mathrm{RC} 1$ & 64.8 & 21.82 & & \multirow{2}{*}{51.35} \\
\cline { 2 - 5 } & $\mathrm{RC} 2$ & 28.0 & 9.42 & \multirow{2}{*}{10.32} & \\
\cline { 2 - 4 } & $\mathrm{RC} 3$ & 28.6 & 9.64 & & \\
\hline
\end{tabular}


The results of this analysis revealed that, the percentage of retention depends on the molar ratio polymer:metal ion, in this particular in this case it was found that the optimal molar ratio for the retention concentration of $\mathrm{Hg}$ (II) was PVATPGal:Hg(II) (20:1).

\section{Influence of the contact time on the interaction $\mathrm{Hg}$ (II) with PVATPGal}

The influence of contact time on the interaction of $\mathrm{Hg}(\mathrm{II})$ at pH 1 with a molar ratio (PVATPGal:Hg(II)) (20:1) was analyzed. Considering the results obtained (Table 6), it is important to note that after 15 min of constant retention higher than $90 \%$ was obtained, so the interaction between the polymer and metal ion occurred fast and effectively. Also, it could be concluded that optimal contact time which allow the highest retention of $\mathrm{Hg}(\mathrm{II})$ at the studied conditions was 60 minutes.

\section{Competitive selectivity in a ternary mixture}

To evaluate the kind of selective retention of mercury (II) versus Cd (II) and Zn (II) a competitive selectivity assay was performed. We used a molar ratio of 20:1 of polymer to the total of metal ions moles. The $\mathrm{pH}$ of the solution was 1 and the contact time was 1 hour. The results are shown on Table 6.

After the competitive assay selectivity, it was observed that the mercury ion remains the most retained, however the retention percent decreased in comparison to the result obtained with the pure solution of this salt (see Table 4).

\section{Elution}

The first assay to evaluate the reusability of the polymer is the determination of optimal eluent that allows the regeneration of the active sites of the polymer. For this purpose, a sample of PVATPGal loaded with $\mathrm{Hg}$ (II) $(0.97 \mathrm{mg}$ ) was eluted with two solutions with different characteristics: ethylenediaminetetraacetic acid (EDTA) and sodium carbonate, both at a concentration of $0.5 \mathrm{M}$. The results after contacting the sample, with each of the separate eluent for an hour with continuous stirring in a thermostatic bath at room temperature, shown that the recovery percent obtained with sodium carbonate was 32.1 meanwhile with EDTA it was $95.7 \%$. After this analysis, it could be concluded that EDTA was an appropriate eluent to remove $\mathrm{Hg}$ (II) from PVATPGal, which is essential to evaluate charge and discharge cycles.

In summary, from all these results it can be concluded that PVATs: retains $\mathrm{Hg}(\mathrm{II})$ at $\mathrm{pH} 1$ and the copolymer saturation occurred at first trial of contact. PVATPHM showed higher retention percent for $\mathrm{Hg}$ (II) at $\mathrm{pH} 1$, and would be useful with $\mathrm{Cu}$ (II) to release retention cycles. Finally, PVATPGal has the highest retention percent for $\mathrm{Hg}$ (II) at $\mathrm{pH}$ 1. Also, this copolymer showed selectivity for $\mathrm{Hg}(\mathrm{II})$ at this $\mathrm{pH}$ under non-competitive and competitive conditions, which was easily eluted with $0.5 \mathrm{M}$ EDTA at a percentage higher than $95 \%$. The optimum conditions of retention were a molar ratio (PVA-Gal: $\mathrm{Hg}(\mathrm{II})$ ) of (20:1) and $60 \mathrm{~min}$ of contact time.

\section{Conclusions}

"Click" reactions had been successfully extended to macromolecules, particularly for PVA modification. The synthetic strategies applied led to novel copolymers with heterocyclic side groups attached to the polymer backbone with quantitative yields. In turn, these heterocycles could present in their structure carbohydrate or hydroxymethyl groups as substituents.
The new copolymers as well as their precursors were fully characterized by spectroscopical and thermal characterizations, from these analyses are can conclude that none of them present decomposition below $200^{\circ} \mathrm{C}$.

It is important to remark that all the copolymers have the ability of removing the analyzed heavy metal ions. However, PVATPGal showed the highest retention level for mercury ion under competitive and non-competitive conditions. Furthermore, the mercury adsorbed in PVATPGal structure could be eluted with EDTA solution of $0.5 \mathrm{M}$, and the copolymer be reused after treatment.

The copolymer containing triazolic rings with galactose residue showed promising results as resin for the cleaning of water contaminated with mercury.

\section{Acknowledgements}

B.L. Rivas thanks to FONDECYT (Grant No 111079) and PIA (Grant ACT 130). The authors wish to thank the financial support of UBACyT No 200220100100142, PICT-2012-0717 and CONICET PIP 112-201101-00370CO, PIP 112-2015-0100443CO.

\section{References}

1. Vega I, Fernández E, Mijangos C, D’Accorso N, López D (2008) Potential applications of poly(vinyl alcohol)-congo red aqueous solutions and hydrogels as liquids for hydraulic fracturing. J App Polym Sci 110: 695-700.

2. Kaity S, Isaac J, Ghosh A (2013) Interpenetrating polymer network of locust bean gumpoly (vinyl alcohol) for controlled release drug delivery. Carbohyd Polym 94: 456- 467.

3. Gaina C, Ursache O, Gaina V, Ionita D (2021) Re-mendable polyurethanes. PolymPlast Technol 5: 65-70.

4. Gao H, Matyjaszewski K (2006) Synthesis of star polymers by a combination of ATRP and the "click" coupling method. Macromol 39: 4960-4965.

5. Yang L-P, Dong X-H, Pan C-Y (2008) Synthesis of inverse star block copolymer by combination of ATRP, ring opening polymerization, and "click chemistry". J Polym Sci Pol Chem 46: 7757-7772.

6. Durmaz H, Dag A, Hizal A, Hizal G (2008) One-pot synthesis of star-block copolymers using double click reactions. J Polym Sci Pol Chem 46: 7091-7100.

7. Gacal BN, Koz B, Gacal B, KisKan B, Erdogan M, et al. (2009) Pyrene functiona poly(vinyl alcohol) by “click" chemistry. J Polym Sci Pol Chem 47: 1317-1326.

8. Chan WK (2007) Metal containing polymers with heterocyclic rigid main chains Coordin Chem Rev 251: 2104-2128.

9. He X, Wang Z, Xing F, Li M (2010) 3D copper coordination polymers based on N-heterocyclic ligands with different topology. Inorg Chem Comm 13: 417-421.

10. Martins Alho MA, Grassi D, Fernández Cirelli A, D’Accorso NB (2009) Copper recovery from aqueous solution by a modified industrial polymer. Environ Chem Lett 7: 271-275

11. Grassi D, Martins Alho MA, Fernadez Cirelli A, D’Accorso NB (2013) Polymer with tetrazolic pendant groups. Interaction between the heterocyclic groups and heavy metals. Trends Heterocyc Chem 16: 33-39.

12. Bakhshoodeh R, Alavi N, Soltani Mohammadi A, Ghanavati H (2016) Removing heavy metals from Isfahan composting leachate by horizontal subsurface flow constructed wetland. Environ Sci Pollut Res.

13. Diop M, Amara R (2016) Mercury concentrations in the coastal marine food web along the Senegalese coast. Environ Sci Pollut Res Int 23: 11975-11984. [Crossref]

14. Alexandratos SD, Wilson DL (1986) Dual mechanism bifunctional polymers: polystyrene based ion exchange/redox resins. Macromol 19: 280-287.

15. Navarro JAR, Lippert B (2001) Simple 1: 1 and 1: 2 complexes of metal ions with heterocycles as building blocks for discrete molecular as well as polymeric assemblies. Coordin Chem Rev 222: 219-250.

16. Rivas BL, Geckeler KE (1992) Synthesis and Metal Complexation of Poly(ethyleneimine) and Derivatives. Adv Polym Sci 102: 171-188. 
17. Molina MJ, Gómez-Antón MR, Rivas BL, Maturana HA, Piérola IF (2001) Removal of $\mathrm{Hg}(\mathrm{II})$ acid aqueous solutions by poly(N-Vinylimidazole) hydrogel. $J$ Appl Polym Sci 79: 1467-1475.

18. Rivas BL, Maturana HA, Molina MJ, Gómez-Anton MR, Piérola IF (1998) Metal Ion Binding Properties of Poly(N-vinylimidazole) Hydrogels. J Appl Polym Sci 67: 11091118 .

19. Rivas BL, Villegas S (2004) Water-insoluble polymers with ability to remove metal ions. J Appl Polym Sci 91: 3679-3685.

20. Rivas BL, Pereira ED, Palencia M, Sánchez J (2011) Water-Soluble Functional Polymers in Conjunction with Membranes to Remove Pollutant Ions from Aqueous Solutions. Progr Polym Sci 36: 294-322.
21. U.S. Environmental Protection Agency (1997) Mercury Study for Congress: Fate and Transport of Mercury in the Environment. EPA-452/R-97-005; Environmental Protection Agency: Washington, DC.

22. Marten ML (2004) In Encyclopedia of Polymer Science and Technology (3rd ed) Kroschwitz JI, Ed.;Wiley: New York, 8: 399-436.

23. Lamanna M, D'Accorso N (2011) New copolymers with heterocyclic pendant groups obtained from PVC using microwave-assisted process. J App Polym Sci 121: 951-956.

24. Campo VL, Carvalho I, Da Silva CHTP, Schenkman S, Hil L, Nepogodiev SA, Field RA (2010) Cyclooligomerisation of azido-alkyne-functionalised sugars: synthesis of 1,6-linked cyclic pseudo-galactooligosaccharides and assessment of their sialylation by Trypanosoma cruzi trans-sialidase. Chem Sci 1: 507-514.

Copyright: (C2017 Lamanna M. This is an open-access article distributed under the terms of the Creative Commons Attribution License, which permits unrestricted use, distribution, and reproduction in any medium, provided the original author and source are credited. 